Daniel Brzeziński

Uniwersytet Warszawski

d.brzezinski3@student.uw.edu.pl

ORCID: oooo-ooo1-5169-4434

\title{
Labirynt tożsamości. Czeczeńska lezginka w perspektywie antropologii tańca
}

\author{
The labyrinth of the identity: Chechen \\ lezginka in the light of the anthropology \\ of dance
}

DOI: $10.12775 /$ LL.4.2021.001 | CC BY-ND 4.o

\begin{abstract}
The paper constitutes an anthropological analysis of a selected form of traditional Chechen dance - the Lezginka. The author formulates a hypothesis on the essential role of this cultural phenomenon in the intergenerational transmission of culture in the Chechen (sometimes referred to as Nakh/Vainakh) community, and on the observable universal traits present in the dance, characteristic for the Chechen collective identity. The author refers to works of American and Polish anthropologists, employing such notions as „embodied knowledge”, „context” and "cultural universals". The author analyses various elements of the dance, including the spiral as a form organizing the dancers' movement, as well as the relationship between the male and female dancers, and also between the dancer and the audience, providing a cultural commentary for each element. The category of the labyrinth is mentioned as well as an important point of reference; the author cites research validating the connection between the Lezginka and the ancient Greek myth of Theseus as well as with the motif of labyrinth as a semantically rich interpretative perspective on Chechen chelchar dance. The final part of the paper presents conclusions on the limitations to which an anthropological analysis of dance forms is subjected.
\end{abstract}

KEYWORDS: Chechen culture, Chechen dance, Lezginka, labyrinth, labyrinth dances, chelchar 
Stwierdzenie, że taniec jest jedną z nielicznych pozostałości po tradycyjnej kulturze Wajnachów ${ }^{1}$, byłoby zapewne przesadne, jednak faktem pozostaje, iż ze stanowiącej przez wieki podstawę czeczeńskiej transmisji kulturowej triady epos - taniec (czecz. chełchar, inaczej lezginka) - pieśń (czecz. illi) (por. Adger-Adajew 2005), obecnie jedynie lezginkę można uznać za powszechnie znaną wśród Czeczenów.

O aktualnym stanie kultury czeczeńskiej decyduje kilka czynników. Najbardziej wyrazistym są wydarzenia historyczne i polityczne, w tym przede wszystkim dwie wojny z Rosją (tzw. wojny czeczeńskie, pierwsza w latach 1994-1996, druga 1999-2009) oraz związane z nimi zmiany w strukturze społeczeństwa - wysoka liczba zmarłych, masowe migracje wewnętrzne i zewnętrzne, a także wywołane kryzysem ekonomicznym zubożenie znacznej jego części w latach 90. XX w. Wtedy właśnie nasiliły się również dwa procesy wpływające na kształt czeczeńskiej obyczajowości - radykalizacja poglądów religijnych części społeczeństwa oraz globalizacja. Obok swoistej, tradycyjnej odmiany islamu pojawiła się nowa, radykalna w obszarze obyczajowości i promująca odrzucenie szeregu elementów dziedzictwa kulturowego - tzw. wahhabizm. Zjawiskiem równie mocno oddziałującym na kształt stosunków społecznych jest polityka, w szczególności stosunek do Rosji i niepodległości samej Czeczenii. Wokół tych dwóch kwestii przebiegają linie najsilniejszych napięć wewnątrz społeczeństwa - zarówno tej jego części, która nie opuściła kraju, jak i licznej, rozsianej po Azji i Europie diaspory. Najwyraźniejszymi ich objawami jest rozluźnienie silnej wcześniej więzi narodowej oraz postępujące znoszenie części reguł stanowiących o stabilności ładu społecznego, który opierał się na patriarchalnej strukturze rodowej o specyficznie demokratycznych cechach. Podstawowymi wartościami leżącymi u jej podstaw były wolność, równość i godność, co wyrażało się w licznych niepisanych zasadach (czecz. adat), regulujących życie jednostek, rodzin i rodów. Ich naruszenie skutkowało jeszcze niedawno - przed wojnami czeczeńskimi - wykluczeniem ze społeczności.

Nadal jednak można wskazać szereg zjawisk, które stanowią o odrębności kultury czeczeńskiej. Poza formami tańca i związanymi z nim rytuałami społecznymi są to bez wątpienia język oraz część funkcjonujących jeszcze zasad adat i nieformalnych instytucji społecznych. Warto zaznaczyć, że pod tym względem społeczeństwo jest mocno zróżnicowane, a paleta postaw obejmuje zarówno te silnie konserwatywne, jak i skrajnie liberalne czy reformatorskie oraz wiele pośrednich. Mimo przemian i nieodwracalnych prawdopodobnie zmian wewnątrz struktury rodowej jako całości dla znacznej części Czeczenów i Czeczenek najważniejszym punktem odniesienia jest rodzina i tejp (grupa rodowa). Rodzinne i rodowe więzi związane są $\mathrm{z}$ nadal funkcjonującymi relacjami władzy, opartymi na zasadach patriarchatu z wyraźnym jednak wpływem kobiet - szczególnie starszych, owdowiałych czy otoczonych szacunkiem z uwagi na zasługi i wiedzę. Silne poczucie przynależności rodowej i wzajemna lojalność

1 Zwyczajowa, używana przez Czeczenów nazwa narodu czeczeńskiego. 
członków tejp wraz z funkcjonującymi także na uchodźstwie zasadami gościnności i szacunku wobec starszych tworzą podstawę współczesnej kultury czeczeńskiej. Jej ważnym składnikiem jest też język czeczeński, funkcjonujący przede wszystkim w komunikacji codziennej, nieraz także wykorzystywany do publicznego podkreślania odrębności narodowej w sytuacji włączenia republiki do Federacji Rosyjskiej.

Warto podkreślić, że to właśnie taniec jest przez samych Czeczenów przywoływany jako ten nośnik wartości ich kultury, tradycji i tożsamości, który nadal jest żywy, to znaczy praktykowany i rozumiany przez całą wspólnotę. Pozostałe elementy wspomnianej triady - a także zabytki tzw. kultury wież, dzisiaj będące już szczątkami na skutek destrukcyjnych działań rosyjskiej armii ${ }^{2}$ - są coraz słabiej rozumiane i coraz mniej wykorzystywane w przekazie międzypokoleniowym. Co prawda mity i pieśni są otoczone szacunkiem, ale przypomina on raczej szacunek do dawnych symboli i archetypów. Wiedza o tym, co oznaczają, staje się dostępna tylko nielicznym osobom wykształconym lub pasjonatom. Inaczej jest w przypadku tańca, który znają „wszyscy”, a jego znajomość bywa traktowana jako wyznacznik przynależności do wspólnoty.

Jeśli więc rozpatrywać ten fenomen kultury w ujęciu synchronicznym, to obecnie lezginka - z zastrzeżeniem, że jest to bardzo pojemny termin, nawet dla samych Czeczenów oznaczający zarówno bardzo konkretne formy tańca, jak i całą klasę zachowań tanecznych w różnych kontekstach i o zróżnicowanej doniosłości kulturowej - stanowi rzeczywisty środek rekonstrukcji, reprodukcji i ekspozycji najistotniejszych treści tego, co sami Czeczeni nazywają nuachczołła (w wolnym przekładzie czeczeńskość, bycie Czeczenem) (Adger-Adajew 2005: 242). Dla obserwatora pochodzącego ze środkowej Europy uderzające jest zarazem to, że współcześnie dla przeciętnego Czeczena czy przeciętnej Czeczenki nie istnieje podział na taniec tradycyjny (ludowy) i współczesny. Zarówno sformalizowane wydarzenia, otwarcie i świadomie nawiązujące do tradycji (jak pokazy tańca, działalność zespołów folklorystycznych, ale też występy zawodowych tancerzy na prywatnych imprezach, takich jak wesela), jak i spontaniczne spotkania młodzieży są momentami, w których korzysta się z tych samych form tańca oraz z podobnego podkładu muzycznego. Co więcej, przyjmując, że taniec pełni funkcję komunikacyjną, w obu przypadkach przekazuje on podobną treść. Interesująca jest zatem sytuacja, w której możliwy jest bezpośredni dostęp do wciąż żywego, powszechnie praktykowanego (a więc i podlegającego zmianom) tańca tradycyjnego, będącego jednocześnie rzeczywistym środkiem wyrazu współczesnych nam członków społeczności. Katherine Dunham, badaczka kultury mieszkańców Haiti, napisała w połowie ubiegłego stulecia: „Taniec jest tak samo ważny, jak pokrewieństwo, organizacja polityczna czy wszelkie inne aspekty życia społecznego. I rzeczywiście, w niektórych kulturach taniec może

2 Wielowiekowa tradycja i technologia budowy kamiennych wież, będących siedzibami rodowymi poszczególnych rodzin-klanów, ustała w XIX w., a na przełomie XX i XXI w. uległa zniszczeniu w czasie tzw. wojen czeczeńskich. 
być kluczem do zrozumienia całokształtu wartości i zachowań” (Dunham 1957, za: Royce 2015: 18). Czy tak właśnie jest w przypadku Czeczenów? Niniejsza praca jest próbą odpowiedzi na to pytanie.

Podstawami moich refleksji są informacje i doświadczenia zebrane w latach 2004-2018, podczas współpracy ze środowiskiem Czeczenów mieszkających w Polsce ${ }^{3}$. Jest to przede wszystkim udział w około 50 wydarzeniach o charakterze tanecznym w roli obserwatora i uczestnika - wydarzeniach należących do kategorii wspólnotowych, wewnętrznych i nieraz spontanicznych, organizowanych przez członków społeczności dla tejże społeczności i zaproszonych gości. Większość z nich odbywała się na terenie ośrodków dla cudzoziemców, ale też w wynajętych salach czy domach prywatnych. Drugą rolą, która pozwalała mi na gromadzenie obserwacji i doświadczeń, była rola animatora kultury, którą pełniłem w tym okresie $\mathrm{w}$ organizacjach pozarządowych wspierających środowisko migrantów. Przy okazji inicjowania i organizowania wydarzeń kulturalnych i edukacyjnych wielokrotnie asystowałem przy tworzeniu choreografii lezginki, obserwowałem naukę tańca i prace instruktorów oraz przygotowania do występów. Wiele cennych informacji wykorzystanych w tej pracy pochodzi też bezpośrednio od członków społeczności oraz organizatorów i uczestników wspomnianych wydarzeń, nie tylko osób narodowości czeczeńskiej, ale także innych świadków, obserwatorów i uczniów.

Za inspiracje, ale przede wszystkim przewodnik metodologiczny, przyjmuje prace antropolożek amerykańskich - Anyi Peterson Royce (2015) i przywoływanych przez nią prekursorek badań nad tańcem: Katherine Dunham, Andrienne Kaeppler i Gertrude Prokosch Kurath - oraz polskich - Jolanty Kowalskiej (1991) i Dominiki Byczkowskiej (2012). Inspirująca okazała się także rozprawa doktorska Tomasza Drożdża (2012). Od Royce zaczerpnąłem samą definicję antropologicznego podejścia do tańca, którą badaczka ujmuje jako:

[...] jedyny sposób na określenie prawdziwego znaczenia tańca w każdej grupie społecznej, ponieważ oferuje ujęcie, które bada pewną całość, w ramach której taniec funkcjonuje. Aby powiedzieć o tańcu coś więcej niż to, co zawierają impresjonistyczne formułki, trzeba go przeanalizować, tj. wydzielić z reszty kultury. [...] Trzeba wierzyć, że da się to wszystko osiągnąc bez większej szkody dla fenomenu (Royce 2005: 39).

Tę samą myśl wyraża Jolanta Kowalska: „Nie może być mowy o interpretacji poszczególnych form tańca ani o ich rzeczywistej znajomości bez wiedzy na temat towarzyszącego im kontekstu kulturowego" (Kowalska 1991: 12). Wielokrotne obserwowanie lezginki w różnych wykonaniach i kontekstach utwierdziło mnie w przekonaniu, że istnieje ścisły związek pomiędzy tą formą tańca a samym

3 Kontakt ze środowiskiem migrantów z północnego Kaukazu umożliwiła mi w tym okresie współpraca ze Stowarzyszeniem Praktyków Kultury, Stowarzyszeniem Teatralnym „Remus” oraz kilkoma ośrodkami prowadzonymi przez Urząd do spraw Cudzoziemców. 
jądrem kultury czeczeńskiej. Uchwycenie tego związku, a właściwie jego werbalizacja, wydawała mi sie poza zasieggiem języka. Przyczynę takiego stanu rzeczy (zarówno mojego poczucia bezradności, jak i specyfiki badań nad tańcem w ujęciu antropologicznym) wyjaśnia stosowana przez Royce kategoria wiedzy ucieleśnionej, uzupełniającejwiedzę intelektualną (Royce 2010: 25). Bardziej precyzyjne będzie więc stwierdzenie, że istnieją dające się obserwować i opisywać związki pomiędzy poszczególnymi aspektami tej formy tańca a niektórymi elementami czeczeńskiej kultury, jednak opis ten powinien opierać się na separacji języka ciała od indywidualnych manifestacji, dzięki czemu „separujemy tym samym to, co społeczne od tego, co indywidualne oraz to, co esencjonalne od tego, co przypadkowe" (Drożdż 2012: 23).

Wiedza ucieleśniona w tym przypadku to moja własna praktyka uczestniczenia $\mathrm{w}$ czeczeńskich chełchar w roli, którą trudno jednoznacznie określić w binarnej opozycji widz-wykonawca, ponieważ w chełchar każdy widz jest potencjalnym wykonawcą, może zostać wciagnięty do tańca w każdej chwili (chociaż podlega to pewnym regułom), a ponadto samo współtworzenie ludzkiego (więc cielesnego) kręgu wyznaczającego teren tańca ma znaczenie symboliczne. Jeśli osoba z zewnątrz wspólnoty bierze w nim udział jednokrotnie, przez przypadek lub przy jakiejś okazji, mamy do czynienia z turystyką. Powtarzana wielokrotnie, uzupełniona rosnącą ilością obserwacji, otwarta na niuanse i świadome uczestniczenie, praktyka ta staje się podstawą wiedzy ucieleśnionej, a co za tym idzie, antropologicznego podejścia do tańca.

Zaskakująco zgodne z wcześniej opisanym brakiem rozróżnienia na czeczeński taniec tradycyjny i współczesny jest radykalne (tzn. szerokie, czyli antropologiczne) traktowanie przez wcześniej wymienione badaczki wszelkich zachowań tanecznych w danej społeczności:

Wszelkie rozbieżności pomiędzy tańcem etnicznym i tańcem artystycznym znikają w obliczu etnologii tańca; nie w sensie opisu czy możliwości odtwarzania określonego rodzaju tańca, ale dzięki podejściu i sposobom ukazywania miejsca tańca w życiu człowieka - słowem dlatego, że jest gałęzią antropologii (Kurath 1960, za: Royce 2015: 43).

Dzięki takiemu ujęciu łatwiej jest uchwycić zachowania taneczne współczesnych Czeczenów i Czeczenek jako wyraz obecnych w kulturze elementów i pojęć, niezależnie od zmieniających się - w ostatnich dekadach dynamicznie i na niespotykaną wcześniej skale - uwarunkowań zewnętrznych (jednym z nich jest zjawisko masowej migracji w trakcie i po wojnach czeczeńskich).

Skoro, jak stwierdza Adrienne Kaeppler, „w odpowiednim opisie kultury nacisk położony na taniec powinien być adekwatny do tego, jaki kładą nań członkowie tego społeczeństwa” (Kaeppler 1967, za: Royce 2015: 40), warto przywołać głos przedstawiciela Wajnachów - Issy Adger-Adajewa. To właśnie jego praca, będąca jedyną polskojęzyczną monografią czeczeńskiej kultury, stanowi źródło pojęć i wiedzy o niej. „W chetchar - pisze autor - w pełni wyraża się duch narodu. 
Być Czeczenem to właśnie mieć chełchar w genach: czeczeńskość tancerza wyraża się w chełchar k'eż (dosłownie znaczy to stan wrzenia) - czymś nie do naśladowania i nie do nauczenia nawet w najlepszych szkołach tańca” (Adger-Adajew 2005: 242). W lezgince skupia się więc jak w soczewce esencja czeczeńskiej kultury, co upoważnia obserwatora-uczestnika do stawiania pytań o podobieństwa między samym tańcem a obecnymi w tej kulturze powszechnikami. Część z tych uniwersaliów widoczna w tańcu związana jest z kategorią labiryntu, a konkretnie kreteńskim mitem o Tezeuszu i Ariadnie, co pokażę, korzystając z klasycznej w tym obszarze pracy Paolo Santarcangeliego (1982) oraz niezwykle cennych spostrzeżeń autorów opracowania Tezeusz w labiryncie (Kowalski, Krzak 1989). Poniższa analiza jest zbudowana na wzór ruchu tancerzy chetchar. Zaczyna się od warstw zewnętrznych (czyli tych najlepiej widocznych, ale też najchętniej prezentowanych, a więc uzewnętrznianych), następnie przechodzi do środka (do sedna, czyli w tym przypadku kategorii labiryntu), a potem z powrotem na zewnątrz. Moje obserwacje obejmą kolejno: aspekt przestrzenny sytuacji tanecznej, etykietę związaną z zapraszaniem do tańca, reguły zachowania się wewnątrz kręgu i - jako sedno rozważań - formę spirali, organizującą ruch tancerki i tancerza chełchar. Ścieżką wyjścia z kręgu, czyli dopełnieniem obrazu widocznych przez ramy tańca elementów kultury czeczeńskiej, będą odniesienia do relacji tancerz-wspólnota.

Przy różnych okazjach można obserwować wiele odmian i form lezginki jako męski lub żeński taniec solowy, jako układ zbiorowy grupy osób jednej płci, choreografię wielu par lub taniec jednej pary (kobiety i mężczyzny). Ta ostatnia forma jest przedmiotem niniejszej analizy, wybór zaś nie jest przypadkowy. Przemawiają za nim dwa argumenty. Przede wszystkim, jest to forma przez samych Czeczenów uznawana za jedną z najważniejszych lub wręcz najważniejszą, czyli niosącą największą ilość znaczeń, najlepiej wyrażającą nuochczołła i jednocześnie najbardziej uniwersalną, to znaczy realizowaną w różnych kontekstach i różnorodnych celach. Ponadto, wybór do analizy tej formy lezginki podyktowany jest moim własnym doświadczeniem obserwatora-uczestnika. „Teraz ty, twoja kolej, no, dalej, śmiało! Zobacz, ją zaproś, tę tam, musisz wyjść, zatańcz, no!” - tak w skondensowanej formie można przedstawić zestaw argumentów prezentowanych, a dokładniej rzecz ujmując wykrzykiwanych do ucha przy jednoczesnym popychaniu i poklepywaniu po plecach w sytuacji, gdy ktoś spoza wspólnoty bierze udział w chełchar. Taka osoba, zresztą niezależnie od płci, jest przez pozostałych uczestników (w przypadku mężczyzny) lub uczestniczek (w przypadku kobiety) stanowczo zachęcana do spróbowania, do doświadczenia, do działania. W przypadku innych form lezginki osoby spoza grona tancerzy są tylko obserwatorami.

Działaniem tym jest taniec wykonywany w parze, wewnątrz „kręgu” (cudzysłów jest tutaj niezbędny, gdyż nie zawsze jest to dosłownie figura kręgu czy też okręgu - nieraz jest bardziej kwadratowa lub owalna) złożonego ze wszystkich osób biorących udział w sytuacji, niezależnie od płci i wieku. Osoby te, jak wspomniałem, chwilowo widzowie, ale potencjalnie wykonawcy tańca, podzielone są 
wyraźnie na dwie grupy - męską i żeńską. Wewnątrz obu tych grup dostrzegalne są inne podziały, związane $\mathrm{z}$ wiekiem i pozycją społeczną, a także umiejętnościami tanecznymi, ale ten pierwszy pozostaje nienaruszalny, te pozostałe zaś podlegają niuansom i interpretacji. Przykładowo, młodsze dzieci i nastolatkowie mogą wmieszać się w grupę dorosłych, a młodzież może stać w kręgu w sąsiedztwie starszej osoby. Wymieszać w kręgu mężczyzn (czy też chłopców) i kobiety (dziewczynki) jest nie do pomyślenia. Już to proste spostrzeżenie naprowadza obserwatora na jeden $\mathrm{z}$ ważnych tropów interpretacji zarówno samego chełchar, jak też kultury czeczeńskiej jako całości. Jeśli do tej obserwacji dodać tę, że w środku kręgu mu si znajdować się para kobieta-mężczyzna, przeoczenie podziału społeczności według kategorii płci staje się niemożliwe. Zanim jednak przejde do analizy charakteru tej relacji, chciałbym wskazać na dwoisty charakter figury geometrycznej, o której mowa.

W rozdziale piątym pracy Taniec drzewa życia, pt. Symbolika granicy, Jolanta Kowalska szczegółowo opisuje różne przykłady zakorzenionych kulturowo sposobów podkreślania limes, stawiania niewidocznej linii pomiędzy „nami” a „nie-nami”. Jednym z nich jest kształt koła/okręgu, obecny w wielu formach tanecznych (Kowalska 1991: 110-120). Jego podwójna funkcja i zarazem symbolika (z jednej strony budowanie wspólnoty, z drugiej oddzielanie tego, co wewnątrz od tego, co na zewnątrz) łatwo wpisuje się w proces interpretacji lezginki. Nie miałaby ona bowiem racji bytu bez owego „kręgu”. Jest ona zawsze wykonywana wobec zgromadzonych wokół osób. To one tworzą ramę tańca - dosłownie, czyli stojąc, klaszcząc, kibicując, wzniecając chełchar k'eż, ale też symbolicznie, gromadząc się wokół tego, co najbardziej reprezentatywne i esencjonalne w ich kulturze. Wydarzenie taneczne jest więc konstruowane w pełni społecznie: chętni do tańca młodzi ludzie, wyznaczone miejsce i czas, muzyka (na żywo lub odtwarzana), wszystko to nie wystarczy, potrzebna jest wspólnota, której obecność tworzy sytuację, w jakiej lezginka uzyskuje sens. Sensem tym zaś jest z pewnością potwierdzanie istnienia samej wspólnoty, co wydaje się istotne zarówno obecnie, w czasach masowej (przymusowej) migracji i globalizacji, jak w przeszłości, gdy Wajnachowie tworzyli silną, zwartą grupe społeczną.

Istnienie wspólnoty to pewna podstawa, wyrażana nawet nie tyle w samym tańcu, co przez przestrzenno-społeczną konstrukcję samej sytuacji tanecznej. Stworzenie „kręgu” to jednak w przypadku lezginki coś więcej. W regułach obowiązujących wszystkie obecne osoby dostrzec można także bardziej ukryte, a jednocześnie fundamentalne dla czeczeńskości ryty. Ogólną zasadą, o której już wcześniej wspomniałem, jest potencjalna możliwość (przyjaznego i dość stanowczego zarazem) bycia zaproszonym do tańca w każdej chwili. Interesujący wydaje się tu sposób dobierania się pary. Mężzyzna (bądź chłopiec) - nigdy kobieta - rozpoczyna taniec, wychodząc na środek i ukłonem zaprasza do pary wybraną kobietę (dziewczynkę). To, czego obserwator może się nie spodziewać, to duża dowolność w tym wyborze, szczególnie jeśli chodzi o wiek. Przede wszystkim nie ma przeszkód, by mały chłopiec zaprosił do tańca dorosłą 
kobietę, co więcej, tancerka potraktuje go jako pełnoprawnego partnera w tańcu i zachowa się dokładnie tak, jak gdyby to był dorosły. Nieco rzadziej obserwuje się sytuacje odwrotne, ale one też są dopuszczalne. Dla dziewczynki zaproszenie przez dorosłego lub dorastającego tancerza może być wręcz wyróżnieniem, a on z kolei, jeśli już zaprosi ją do pary, da z siebie tyle, ile w tańcu ze swoją rówieśniczką. Jest to sytuacja emblematyczna dla kultury czeczeńskiej: szacunek należy się każdemu, bez względu na wiek. „Wyrażam szacunek przyszłej kobiecie i matce, kłaniając się dziewczynce, a z godnością witając chłopca, oddaję część mężczyźnie, którym się stanie" - tak można streścić postawę obecną w codzienności wielu czeczeńskich rodzin, dla których czeczeńskość to właśnie wzajemny szacunek, w tańcu okazywany szczególnie ostentacyjnie.

Drugą istotną właściwością kultury Wajnachów, którą odnaleźć można w „kręgu" tanecznym chetchar, jest egalitaryzm. Mimo skomplikowanej i precyzyjnej struktury rodowej społeczeństwo czeczeńskie jest pod wieloma względami „płaskie”. Wiąże się to z pojęciem honoru i szlachetności, które może zdobyć każdy. Nie mają one źródła w pochodzeniu ani wieku. Największym szacunkiem otacza się osoby o nieposzlakowanej opinii, wykazujące się rozwagą, mądrością i szlachetnością. Przez wieki na tych wartościach opierał się system władzy Wajnachów. W tańcu zaś ujawnia się on właśnie w sytuacji doboru partnerów: każdy może spróbować, teren jest wyznaczony i otwarty dla każdego, więc tylko własna determinacja oraz umiejętności ograniczają nasz dostęp do uznania i podziwu ze strony wspólnoty. Dla mnie, osoby z zewnątrz, ujmujące jest też to, że uznanie oraz podziw są dostępne także dla nie-Czeczenów i nie-Czeczenek. Liczy się odwaga wstąpienia na plac, podjęcia wyzwania i gotowość do wykrzesania z siebie tanecznego stanu wrzenia. Każda próba witana jest z szacunkiem, nawet jeśli kroki okazują się zbyt trudne, rytm zbyt nieoczywisty, a gesty mało efektowne.

Jak wskazałem wcześniej, zanim jeszcze taniec zacznie się na dobre, rozpoznawalne są istotne jego cechy, które można, zgodnie $\mathrm{z}$ wiedzą o kulturze wajnachskiej, uznawać za jej uniwersalia. Przed opisem samej choreografii chciałbym jeszcze wrócić do kwestii dialogu płci, który dla lezginki jest swoistą mocą sprawczą. Jak wspomniałem, zarówno „krąg”, jak i parę wykonującą taniec, zawsze tworzą osoby obojga płci. Naczelną zasadą jest zupełny i nienaruszalny zakaz kontaktu fizycznego, co więcej - zachowanie obojga osób tańczących podlega ścisłym regułom. Jak pisze Issa Adger-Adajew:

Nie tylko fizyczny kontakt jest absolutnym tabu, ale także jakiekolwiek przejawy poufałości czy zalotności w ruchach, spojrzeniu i mimice tańczących. [...] Jednak przy całej obowiązującej dyscyplinie, w tym nasyconym temperamentem i zmysłowością tańcu pozostaje ogromne pole dla wyrażenia własnej osobowości i zaprezentowania budzących społeczne uznanie cech charakteru (Adger-Adajew 2005: 175-187).

Autor trafnie oddaje napięcie, jakie powstaje między żywiołowym tańcem a skutecznie powstrzymującymi jego energię regułami zachowania wobec płci 
przeciwnej. To napięcie wydaje się charakteryzować także takie czeczeńskie instytucje społeczne, jak zawieranie znajomości, szukanie i wybór narzeczonych czy zdobywanie i utrzymywanie uznania oraz szacunku. $Z$ jednej strony podkreśla się, że „młodzi” (w ostatnich dekadach chodzi także o osoby dorosłe w każdym właściwie wieku, co wiąże się z wpływem zarówno wojen, jak i przemian kulturowych) mają pełną swobodę w wyborze partnerów i partnerek, co wyraża się $\mathrm{w}$ lezgince poprzez tryb wybierania osoby do pary. $Z$ drugiej jednak strony, w rzeczywistości wybór w ła ści we go kandydata na narzeczonego lub narzeczoną jest często ściśle kontrolowany przez osoby decydujące o sytuacji rodu, najczęściej są to starsi mężczyźni bliżej lub dalej spokrewnieni z zainteresowanymi „młodymi”, nieraz też jednak wpływ na decyzje mają cieszące się poważaniem kobiety: matki, ciocie, babcie. Dialog płci jest więc w czeczeńskim chełchar bardzo przekonujący i prawdziwy, bowiem przy pełnym zaangażowaniu w energiczny i fizycznie wymagający taniec, tancerze narażaja się na zdecydowaną, negatywną reakcję wspólnoty w przypadku drobnego nawet naruszenia obowiązującej etykiety. Jest to sytuacja powstrzymywania się, świadomego nieraz docierania do umownej granicy akceptowalnego zachowania i na tej granicy balansowania, nie w celu prowokacji - w mojej ocenie raczej okazania zgromadzonym, że te granice dostrzega się, zna i respektuje. Tancerz ma bowiem dużą swobodę w doborze kroków, ruchów rąk i kierunków. Od jego inwencji i odwagi (a także znajomości owych limes) zależy, czy wzbudzi podziw i uznanie. Dotyczy to, chociaż w inny nieco sposób, zarówno mężczyzn, jak i kobiet. Tancerze realizują to wyraźniej, bardziej dosłownie, ponieważ ich taniec jest też bogatszy w kroki i gesty. Tancerki mają do dyspozycji bardziej wyrafinowane i mniej dostrzegalne środki, w pełni jednak zrozumiałe dla partnera i obserwatorów.

Najsilniejszą jest zarezerwowana dla kobiety możliwość przerwania sekwencji tańca w dowolnym właściwie momencie. Ma ona prawo uczynić to nawet po pierwszych kilkunastu taktach, komunikując, że dalszego ciągu nie będzie. Może także nie kończyć tańca bardzo długo, a tancerz ma obowiązek z pełnym zaangażowaniem tańczyć dalej. Obie te skrajne sytuacje, jak i wiele pośrednich, mają wartość komunikatu - czytelnego, chociaż nieraz prowokacyjnego lub podszytego złośliwością. I ta cecha lezginki także wyraża w jakiś sposób istotny dla procesów matrymonialnych aspekt kultury Wajnachów. Kobieta ma prawo odmówić i prawo to, chociaż nie zawsze respektowane, dotyczy także sytuacji już zawartego i trwającego małżeństwa, czyli krótko mówiąc, ma prawo do rozwodu. Czy w codziennym życiu zawsze kobieta decyduje we własnych sprawach? $\mathrm{Na}$ pewno nie, szczególnie w brutalnych i nieuczciwych z definicji czasach wojennych i powojennych. $\mathrm{W}$ tańcu jednak cały czas tak.

Para tancerzy wstępuje w krąg utworzony przez klaszczących rytmicznie widzów, rozpoczynając z przeciwległych punktów. Tancerka, płynąc na palcach $\mathrm{z}$ uniesionymi ramionami, gestami dłoni i skłonami ciała prowadzi mężczyznę ku centrum kręgu - ruch odbywa się po niewidzialnej spirali, 
zawsze w kierunku na prawo. Od momentu ich spotkania, następuje „rozkręcanie” spirali: tancerka zaczyna przesuwać się w odwrotnym kierunku, natomiast jej partner jednym ruchem ciała obraca się o sto osiemdziesiąt stopni i staje za jej plecami. Teraz role całkowicie się zmieniają: mężczyzna staje się przewodnikiem, a dziewczyna podporządkowuje się jego umownym gestom [...]. W zakończeniu zapędza ją ku tworzącej półkrąg grupie przyjaciół lub prowadzi ku starszyźnie i wykonuje ostatni, wirtuozerski popis taneczny (Adger-Adajew 2005: 241).

Powyższy cytat opisuje typową choreografię chełchar w wersji, o której mowa. Na uwagę zasługuje kilka jej elementów: kształt „szkicowany” ruchem po spirali do wewnątrz i na zewnątrz, funkcje, jakie przyjmują tancerka i tancerz wobec siebie, a także moment popisowego tańca partnera. Ruch po spirali jest interpretowany przez badaczy jako znak labiryntu (Santarcangeli 1982: 213), meandryczny charakter tańca zaś jako symbol przechodzenia od życia do śmierci i na odwrót (Kowalski, Krzak 1981: 68) lub znak zdobywania wiedzy o sobie i o otoczeniu (Kowalska 1991: 121-128). Symbolika labiryntu stosunkowo łatwo daje sie prześledzić na gruncie kultur śródziemnomorskich.

[...] i cudny taniec, który Dedal w Krecie

Wymyślił Aryjadnie, prześlicznej kobiecie:

Skaczą chłopcy i dziewki wziąwszy się za ręce.

[...]

Raz jak koło (ruch jego ledwie wzrok dostrzegnie,

Gdy go doświadczony garncarz, czyli bystro biegnie)

Uczone stopy w szybkie kręcą kołowroty;

To znowu się mieszając wśród wdzięcznej ochoty,

W tysiącznych kształtach pląsy lekkim robią skokiem (Homer 1972: 245).

W przypadku starogreckiego tańca geranos, którego źródeł badacze dopatrują się w micie o Tezeuszu, a także wielu innych tańców z kręgu oddziaływania kultury hellenistycznej (Kowalski, Krzak 1989: 67-69), związek z opisanym w Iliadzie wątkiem wędrowania do środka labiryntu i wychodzenia z niego jest uzasadniony. Okazuje się jednak, że także lezginka otwiera się na interpretacje idące w tym kierunku. Jako jeden z pierwszych podjął ten trop czeczeński etnolog Said-Magomed Khasiev . Według niego taniec podzielony jest na kolejne części zgodne z fabułą mitu. Jego pierwsza część, gdy tancerka i tancerz zmierzają do wnętrza, czyli ku środkowi kręgu, jest wejściem Tezeusza do labiryntu i poszukiwaniem jego centrum. W środku ma miejsce spotkanie zaznaczone zmianą kierunku ruchu obojga, ale także formą gestów i wzajemną relacją w przestrzeni. Wówczas następuje ruch po spirali w przeciwnym niż wcześniej

4 Rękopis jego pracy zatytułowanej Tezei jest niedostępny, tezy tam zawarte znajdują się w cytowanej monografii Issy Adger-Adajewa. 
kierunku, czyli „rozwijanie labiryntu”. Na poparcie tezy o starożytnej genezie tej formy tanecznej autor przywołuje m.in. fakt, że labirynt, szczególnie w formie spirali, jest nieodłącznym elementem ornamentyki kultur archeologicznych z terenu północnego Kaukazu, a więc miejsca zamieszkania Czeczenów od XI w. naszej ery (chodzi tu w szczególności o zabytki kultury kobańskiej5). Pozostałe argumenty mające potwierdzać związek kultury tanecznej Wajnachów z grecką mitologią dotyczą leksyki i toponimii. Badacze wskazują też na szerszą obecność wątków helleńskich w czeczeńskich przekazach kulturowych. Zachowane z czasów kultury oralnej fragmenty eposów i pieśni wykazują zaskakujące podobieństwo do mitów o Prometeuszu, Odysie czy Argonautach (Adger-Adajew 2005: 273). Odpowiednikiem tego pierwszego byłby w opowieściach czeczeńskich Pharmat - bohater zdobywający boski ogień, dobroczyńca ludzkości. Niezależnie od oceny trafności takich analogii należy uznać, że możliwe zakorzenienie chełchar w tradycji sięgającej czasów antycznej Grecji pomaga zrozumieć szczególną pozycję tego fenomenu w kulturze czeczeńskiej. Jego symboliczny przekaz dotyczy drogi poznania siebie, w której bohaterowi (tancerzowi) towarzyszy przewodniczka (tancerka); odnosi się także do zwycięstwa $\mathrm{w}$ walce (moment dynamicznego popisu tancerza) i powrotu do domu. Wszystkie te motywy znajdują odpowiedniki zarówno w konkretnych partiach choreografii, jak i wartościach kulturowych czy społecznych. Jednym z centralnych pojęć czeczeńskiej obyczajowości jest szlachetność, której istotnym elementem musi być samokontrola połączona $\mathrm{z}$ wiedzą o świecie i jego regułach. Szeroko pojęte męstwo i odwaga (także cywilna) to elementy zapewniające utrzymanie pozycji osoby honorowej, a więc dążącej do zdobycia szacunku wspólnoty (czyli symbolicznego wejścia do domu).

Ujawnia się tutaj także szczególna funkcja tańczącej pary. Jak stwierdza Jolanta Kowalska, „ograniczenie grupy tancerzy do przedstawicieli jednej płci jest $\mathrm{z}$ reguły sygnałem, że działanie dokonywane za pośrednictwem tańca skoncentrowane jest na tym aspekcie rzeczywistości, który przez osoby swych członków reprezentuje zespół tancerzy. Wspólny udział kobiet i mężczyzn zawiera natomiast odwołania do idei pełni w różnych jej aspektach" (Kowalska 1991: 153). $\mathrm{W}$ lezgince idea ta realizuje się poprzez wymianę funkcji w tańcu. $\mathrm{W}$ jego pierwszej części to kobieta prowadzi, wskazuje drogę, w drugiej zaś - mężczyzna. Brak któregokolwiek z partnerów uniemożliwia realizację pełnej formy. Tancerz, który wychodzi na środek i zaprasza do pary, stwarza sytuację nie do odwołania. Nawet jeśli, co zdarza się rzadko, wybrana kobieta odmówi tańca, mężczyzna zwraca się do następnej. Nie może zrezygnować. Wstępując do kręgu (labiryntu) nie wyjdzie z niego, dopóki nie dokona się spotkanie w tańcu pomiędzy nim a tancerką. Jest to doświadczenie dosłowne i fizyczne: krąg nie przyjmuje z powrotem tego, kto nie przeszedł odpowiedniej drogi. Do wspólnoty nie

5 Jest to identyfikowana na podstawie źródeł archeologicznych kultura późnej epoki brązu i wczesnej epoki żelaza (ok. XV-IV w. p.n.e.), charakterystyczna dla centralnej części północnego Przedkaukazia. 
może należeć osoba bez odpowiedniej wiedzy. Chodzi o samowiedzę: znajomość zasad regulujących życie tej wspólnoty na wielu poziomach. Jednym z nich jest jednak zupełnie przyziemna, namacalna umiejętność - umiejętność tańca. Dzieci są włączane i zachęcane do udziału w chełchar właśnie po to, by stały się tancerzami, by poznały reguły tańca i nabyły umiejętności tanecznych.

$\mathrm{Z}$ potwierdzaniem przynależności do wspólnoty wiąże się znaczenie ostatniego ze wskazanych elementów choreografii, który ponownie kieruje uwage obserwatora na zewnętrzny obszar „sceny”. Chodzi o występujący pod koniec tańca krótki moment popisu, w czasie którego tancerz, przywiódłszy partnerkę w pobliże swoich przyjaciół i krewnych, wykonuje serię najbardziej energicznych i efektownych kroków oraz gestów. Jest to ważny moment szczególnego zaangażowania zarówno tancerza, jak i publiczności. Zwracając się do swojego najbliższego otoczenia, tancerz potwierdza przynależność do grupy, zdobywając jednocześnie pożądany szacunek i uznanie. Tym większe, im większe wrażenie robi jego popisowy taniec. Grupa w tym momencie jest bardzo aktywna, chociaż nie tańczy. Głośno, energicznie i radośnie zachęca tańczącego do jak największego wysiłku, klaszcząc i krzycząc. To kulminacja całej lezginki, a więc także istotny trop interpretacji kulturowej.

Warto w tym miejscu wskazać, że grupa przyjaciół i krewnych to obok rodu niezwykle ważny element czeczeńskiego systemu relacji społecznych. Trudno sobie wyobrazić jakiekolwiek ważne wydarzenie w życiu Czeczena, szczególnie młodego, bez udziału tej grupy. To ona jest katalizatorem kluczowych decyzji i procesów, takich chociażby jak ślub. Dość powiedzieć, że pan młody nie jest obecny na własnym weselu; jest to absolutnie zakazane. Spędza czas w gronie przyjaciół. Jest to więc relacja oparta na zaufaniu i dużej przejrzystości. W takiej grupie nie ma wielu sekretów czy intryg. Analogiczną instytucją społeczną jest grupa przyjaciółek oraz krewnych narzeczonej i większości młodych Czeczenek.

Jak starałem się wykazać, wajnachski chełchar jest przykładem tańca dobrze zakorzenionego w kulturze. Odgrywa jednocześnie istotną rolę w przekazywaniu kluczowych zasad organizacji społeczności czeczeńskiej i wskazówek co do pożądanych wzorów zachowania. Jest więc narzędziem międzypokoleniowej transmisji kulturowej, co nie oznacza, że przekazywane treści mogą być przez dowolnego tancerza czy tancerkę zwerbalizowane i wyrażone w języku pisanym czy mówionym. Nie stoi to jednak na przeszkodzie poznawania i analizowania tego fenomenu z perspektywy antropologicznej. Jak bowiem twierdzi Anya Peterson Royce,

[w]śród wielu sposobów stosowanych przez antropologów do skracania [...] dystansu dzielącego ich od ludzi, których historie i życie starają się zrozumieć, jest dobra znajomość lokalnego języka. [...] Środowisko antropologów zaczyna powoli doceniać znaczenie innego rodzaju języka badań terenowych - języka ucieleśnionego. Jego zastosowanie wymaga większej wrażliwości i otwartości na zranienie, niż jesteśmy to w stanie 
zaakceptować ze względu na nasz komfort [...], ale zyskamy dzięki temu nowy model badań terenowych, który zagwarantuje powodzenie prac nawet bez thumacza (Royce 2015: 24).

Jest dla mnie jasne, że obserwacja i analiza tańca oraz uczestnictwo w nim pozwalają zrekonstruować wybrane elementy kultury, niektóre wartości oraz wyjaśnić pewne zachowania. Taniec jest więc oknem, które pozwala wejrzeć do wnętrza tej kultury, ale pole obserwacji jest ograniczone rama. Poza granicami tego pola są miejsca nieobecne w ekspresji tanecznej. Dla Jolanty Kowalskiej inspiracją, a nawet - jak sama pisze - iluminacją w procesie określania roli człowieka w tańcu, był mit o stwórczym tańcu Siwy-Nataradży. Człowiek jako tańczące centrum to figura zarówno obfitująca w znaczenia, jak i ułatwiająca utrzymanie antropologicznej perspektywy. W przypadku tańca czeczeńskiego także mit - tym razem jednak grecki - jest centralnym punktem odniesienia. Czy przywołanie go wyjaśnia lezginkę w jej niezwykłej, intensywnej i skondensowanej formie współdziałania dwojga ludzi wobec obecnych członków społeczności? Czy znajomość mitu kreteńskiego pozwala wnioskować o przyczynach dzisiejszych zachowań Czeczenek i Czeczenów w ich „tu i teraz”? Czy umożliwia przewidywanie ich zachowań w przyszłości? Oczywiście nie. Eksploracja krętych ścieżek tożsamościowego labiryntu pozwala jednak zbliżyć się do odpowiedzi na pytanie zadawane przez antropologię tańca, a mianowicie: Dlaczego człowiek tańczy?

\section{BIBLIOGRAFIA}

Adger-Adajew, I. (2005). Kamienie mówia. Dzieje i kultura Czeczenów (przeł. K. Brodacka). Warszawa: Instytut Kultury Narodów Kaukazu.

Byczkowska, D. (2012). Ciało w tańcu. Analiza socjologiczna. Łódź: Wydawnictwo Uniwersytetu Łódzkiego.

Drożdż, T. (2012). Człowiek i taniec. Systemy choreograficzne jako profile badania kultury. Praca doktorska pod kierunkiem E. Kosowskiej. Katowice: Uniwersytet Śląski.

Dunham, K. (1957). Les Dances d'Haiti. Paris: Fasquelle.

Homer (1972). Iliada (przeł. F. Dmochowski). Kraków: Wydawnictwo Literackie.

Kaeppler, A. (1967). The structure of Tongan Dance. Hawaii: University of Hawaii.

Kowalska, J. (1991). Taniec drzewa życia. Uniwersalia kulturowe w tańcu. Warszawa: Instytut Kultury Materialnej PAN.

Kowalski, K., Krzak, Z. (1989). Tezeusz w labiryncie. Wrocław-Warszawa: Ossolineum.

Kurath, G. P. (1960). Panorama of Dance Ethnology. Current Antropology, 1(3), 233-254.

Royce, A. (2010). Antropologia sztuk widowiskowych (przeł. N. Moszkowicz). Warszawa: Wydawnictwo Uniwersytetu Warszawskiego.

Royce, A. (2015). Antropologia tańca (przeł. J. Łumiński). Warszawa: Wydawnictwo Uniwersytetu Warszawskiego.

Santarcangeli, P. (1982). Księga labiryntu (przeł. I. Bukowski). Warszawa: Wydawnictwo Wiedza Powszechna. 